\title{
KEKERASAN SIMBOLIK DALAM NOVEL INDONESIA
}

\author{
Sri Wahyuni, Haris Supratno, Kamidjan
}

Program Studi Pendidikan Bahasa dan Sastra, Pascasarjana Universitas Negeri Surabaya

Jalan Ketintang Baru VXII No. 49 Surabaya, Jawa Timur

Surel: sriwahyuni16070825054@mhs.unesa.ac.id

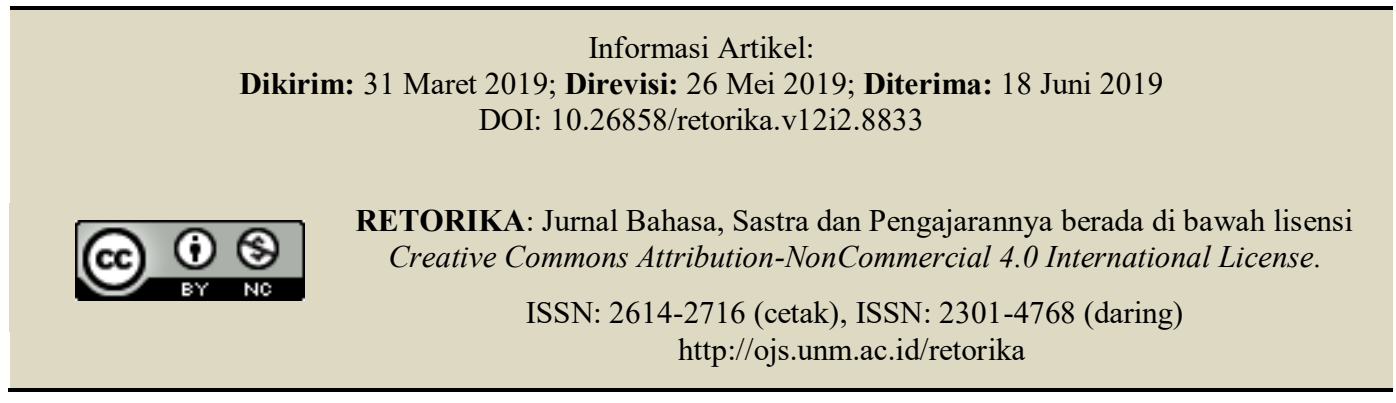

\begin{abstract}
Symbolic Violence in Indonesian Novels. The general objective of this research is to find out the mechanism of symbolic violence, upper class habitus, and lower class habitus in the Indonesian novels. The approach used in this research is a qualitative approach. Data is collected using the documentation method. The results of the study of the mechanism of symbolic violence consisting of euphemisms in the form of compassion, giving, refusal are subtle. The censorship mechanism in the form of positive moral preservation in the form of honor and politeness. Upscale habitus in the form of hopes and lifestyles possessed by social groups above and class habitus under expectations and lifestyles owned by social groups below.
\end{abstract}

Keyword: mechanism of symbolic violence, euphemism, sensorization, habitus

Abstrak: Kekerasan Simbolik dalam Novel Indonesia. Tujuan umum penelitian ini adalah untuk mengetahui mekanisme kekerasan simbolik, habitus kelas atas, dan habitus kelas bawah dalam novel Indonesia. Pendekatan yang digunakan dalam peneltian ini adalah pendekatan kualitatif. Data dikumpulkan dengan menggunakan metode dokumentasi. Hasil penelitian mekanisme kekerasan simbolik terdiri atas eufemisme berupa belas kasih, pemberian, penolakan secara halus. Mekanisme sensorisasi berupa pelestarian moral posiif berupa kehormatan dan kesopanan. Habitus kelas atas berupa harapan dan gaya hidup yang dimiliki oleh kelompok sosial atas dan habitus kelas bawah berupa harapan dan gaya hidup yang dimiliki oleh kelompok sosial bawah.

Kata kunci: mekanisme kekerasan simbolik, eufemisme, sensorisasi, habitus 
Karya sastra adalah cerminan cerita kehidupan masyarakat. Kejadian atau fenomena yang diangkat oleh pengarang dalam karya sastra mencakup semua aspek dalam kehidupan sehari-hari. Karya sastra tidak terlepas dari korelasi antarindividu maupun antarkelompok. Proses korelasi antarindividu maupun antarkelompok dari segi kelas sosial yang berbeda (modal, kedudukan) bukanlah hal yang mustahil apabila terjadi tindak kekerasan, baik berupa kekerasan fisik maupun kekerasan simbolik. Bourdieu (1990 \& 1998) mengemukakan bahwa kekerasan simbolik merupakan kekerasan yang lembut. Disebut sebagai kekerasan yang lembut karena bentuknya samar sehingga tidak tampak sebagai sebuah kekerasan, tersembunyi atau terselubung melalui doktrin, loyalitas, hadiah, pengakuan, balas budi, atau melalui etika kehormatan

Novel Suti dan novel Gumam Tebing Menoreh merupakan novel Indonesia yang mengandung unsur kekerasan simbolik. Kekerasan simbolik dilakukan oleh kelompok kelas atas terhadap kelompok kelas bawah. Cerminan kekerasan simbolik yang terdapat dalam kedua novel tersebut terlihat pada cara-cara yang dilakukan oleh kelompok sosial atas dalam memaksakan dan mensosialisasikan kebiasaan, budaya, dan nilai-nilai yang diyakini oleh kelompok sosial atas. Serangkaian budaya, kebiasaan, dan nilainilai tersebut disebut dengan habitus. Habitus yang dimiliki oleh setiap kelompok sangatlah berbeda. Kelompok sosial atas oleh Bourdieu diistilahkan sebagai pendominasi, sedangkan kelompok kelas bawah diistilahkan sebagai terdominasi.

Dengan didukung kepemilikan modal, kelompok kelas atas (pendominasi) menjalankan aksinya dengan lancar tanpa menerima protes dari yang didominasi. Hal tersebut sesuai dengan pendapat Bourdieu (1990:56) bahwa kekerasan simbolik berjalan karena pengakuan, kesediaan, dan keterlibatan suka rela dari yang didominasi.

Orang yang mendapatkan tindak kekerasan simbolik cenderung tidak melakukan perlawananan karena hal tersebut dianggap sebagai sebuah kewajaran yang memang seharusnya terjadi. Hal tersebut sesuai dengan pendapat Rusdiarti (2003:39) yang mengemukakan bahwa kekerasan simbolik menimbulkan efek kepatuhan dan tidak dirasakan sebagai suatu paksaan dengan berpijak pada harapan yang telah mendarah daging secara sosial. Kekerasan simbolik menimbulkan efek penerimaan.
Bourdieu secara bergantian menggunakan istilah "kekerasan simbolik" (symbolic violence), "kuasa simbolik "(symbolic power) dan "dominasi simbolik"e (symbolic dominance) untuk merujuk pada hal yang sama. Bourdieu merumuskan pengertian ketiganya sebagai" kuasa untuk menentukan instrumen-instrumen pengetahuan dan ekspresi kenyataan sosial secara semenamena, tetapi kesemenaannya tidak disadari. Dalam arti inilah kuasa simbolik merupakan "kuasa untuk merubah dan menciptakan realitas, yakni mengubah dan menciptakannya sebagai diakui dan dikenali secara absah" (Bourdieu: 1995:168).

Kekerasan dan kekuasaan simbolik tidak menggunakan kekangan secara fisik, melainkan melalui dominasi atas pengakuan dan persetujuan yang terlepas dari kesadaran dan dijalankan menjadi habitus (Bourdieu, 2010:54). Kekerasan simbolik berlangsung karena terdapat symbolic power yang dimiliki kelas atas. Symbolic power adalah sebuah potensi untuk mendesak sebuah tujuan kepada pihak lain yang berlaku dan dibenarkan dari masyarakat dan perpecahan dalam masyarakat tersebut (Link dan Phelan, 2013: 25).

Konsep kekerasan simbolik yang dikemukakan oleh Bordieu menjelaskan tentang cara yang digunakan kelas dominan atau kelas atas dalam struktur sosial masyarakat untuk memaksakan pola pikir, budaya, atau gaya hidup pada golongan kelas bawah. Pola pikir, gaya hidup dan kebiasan disebut habitus. Akibatnya, masyarakat kelas bawah didesak menyetujui, melaksanakan, menerapkan, dan mengakui bahwa habitus kelas atas merupakan sesuatu yang harus dilestarikan dan diterapkan dalam kehidupan sehari-hari (Martono, 2012:5).

Kekerasan simbolik terjadi ketika orang yang didominasi menerima sebuah simbol (konsep, ide, gagasan, keprecayaan, dan prinsip) dalam bentuknya yang distrorsif yang memberikan pengakuan atas sesuatu yang diterima secara distorsif, serta menerapkan kriteria evaluasi kelas dominan untuk menilai diri dan kehidupannya. Di dalam proses dominasi tersebut, sebenarnya terjadi pemaksaan simbolik yang sangat halus, namun yang didominasi tidak menyadari bahwa dirinya dipaksa. Hal yang demikian disebut dengan common sense. Kekerasan simbolik terlihat seperti sebuah bentuk kerja sama yang menghasilkan keuntungan bagi masingmasing pihak yaitu mendominasi dan yang didominasi. Kekerasan simbolik dalam novel Suti dan novel Gumam Tebing Menoreh terlihat seperti bentuk hubungan kerja sama antarindividu dari kelas sosial yang berbeda, seperti hubungan 
kerja sama antara majikan dan pembantu, hubungan antara kepala sekolah dan guru, hubungan antara kiai dan santri. Tujuan dari si pendominasi ialah tetap melanggengkan kekuasaannya di dalam kehidupan masyarakat, sedangkan tujuan dari terdominasi adalah untuk mendapatkan kehidupan yang lebih layak dengan menyandarkan harapan-harapannya pada kelompok kelas atas atau pendominasi.

Kekerasan simbolik termasuk kekerasan yang sifatnya positif karena dampak dari jenis kekerasan, seperti ini tidak menimbulkan luka pada fisik maupun perasaan cemas pada korbannnya. Termasuk pada kekerasan simbolik yang terdapat di dalam kedua novel yang digunakan sebagai objek dalam penelitian ini. Kekerasan sejenis ini menghindarkan tindakan kekerasan pada fisik atau tindakan kriminal. Kelompok terdominasi akan mendapatkan pengetahuan atau hal-hal yang belum pernah diketahui sebelumnya karena mereka berbaur dengan kelompok kelas atas yang mempunyai modal dan pengalaman yang jauh lebih baik dari mereka yang berasal kelompok kelas bawah atau yang terdominasi.

Penelitian-penelitian yang menganalisis tentang kekerasan simbolik pernah dilakukan sejumlah peneliti. Penelitian relevan yang pertama dilakukan oleh Haryanto (2017) berjudul Kekerasan Simbolik Berbasis Gender dalam Budaya Pop Indonesia. Penelitian relevan yang kedua dilakukan oleh Widarmanto (2014) dengan judul Kekerasan Simbolik dalam Karya-Karya Okka Rusmini dan Pramoedya Ananta Toer. Meskipun sama-sama menggunakan teori kekerasan simbolik Bourdieu sebagai teori yang digunakan untuk mengkaji karya sastra dan karya seni baik pada penelitian ini maupun pada penelitian relevan yang sebelumya, namun terdapat beberapa perbedaan. Antara lain, pertama, terletak pada objek yang digunakan. Objek yang digunakan dalam penelitian ini berupa dua novel yang berjudul Suti karya Sapardi Djoko Damono dan novel Gumam Tebing Menoreh karya Siwi Nurdiani.

Objek yang digunakan dalam penelitian relevan pertama adalah budaya pop seperti film, sinetron musik, novel pop, media cetak, dan iklan, sinetron, dan komik. Objek yang demikian lebih luas jenisnya karena selain menggunakan karya sastra, penelitian tersebut menggunakan karya seni sebagai objek penelitiannya. Objek yang digunakan dalam penelitian relevan yang kedua adalah novel-novel karangan Pramodeya Ananta Toer dan Oka Rusmini.

Perbedaan antara penelitian ini dengan penelitian sebelumnya terletak pada fokus. Fokus pada penelitian ini terdiri atas mekanisme kekerasan simbolik, meliputi mekanisme eufemisme dan mekanisme sensorisasi dan dikaitkan dengan habitus. Mekanisme tersebut merupakan cara yang digunakan oleh kelompok kelas atas untuk mensosialisasikan habitus-habitusnya kepada kelompok kelas bawah. Mekanisme kekerasan simbolik yang digunakan untuk mensosialisasikan belum diterapkan oleh peneliti yang lain.

Fokus penelitian relevan yang pertama adalah bentuk-bentuk kekerasan simbolik yang dilakukan oleh laki-laki kepada perempuan dan akar atau penyebab terjadinya kekerasan simbolik yang dilakukan oleh laki-laki kepada perempuan yang terdapat dalam budaya populer Indonesia. Fokus penelitian relevan yang kedua adalah yaitu mekanisme kekerasan simbolik. Widarmanto (2014) menggunakan tambahan unsur doxa yang merupakan wacana atau peraturan yang mendominasi dalam kehidupan masyarakat yang terdapat dalam novel karya Pramoedya Ananta Toer dan Okka Rusmini.

Novel Suti dan novel Gumam Tebing Menoreh merupakan dua novel yang benar-benar merefleksikan cerita-cerita kehidupan nyata di dalamnya. Interaksi antara kedua belah pihak, yaitu pendominasi dan yang terdominasi menghasilkan sebuah efek kekerasan simbolik. Aspek itulah yang menjadikan kedua novel ini penting dikaji dari perspektif kekerasan simbolik.

\section{METODE}

Penelitian ini menggunakan kajian kekerasan simbolik yang meliputi mekanisme kekerasan simbolik, habitus kelas atas, dan habitus kelas bawah. Sumber data pertama dalam penelitian ini adalah novel yang berjudul Suti karya Sapardi Djoko Damono. Novel tersebut diterbitkan oleh penerbit Kompas pada Tahun 2013 yang terdiri atas 192 halaman. Sumber Data kedua adalah novel yang berjudul Gumam Tebing Menoreh karya Siwi Nurdiani. Novel tersebut ditebitkan oleh penerbit Diva Tahun 2018 yang terdiri atas 296 halaman.

Teknik pengumpulan data dalam penelitian ini adalah teknik dokumentasi. Teknik pengumpulan data berupa dokumentasi, yaitu mempelajari dokumen yang berkaitan dengan 
seluruh data yang diperlukan dalam penelitian. Prosedur pengumpulan data dalam penelitian dilakukan dengan memberikan tanda pada data berdasarkan fokus penelitian yaitu mekanisme kekerasan simbolik, habitus kelas atas, dan habitus kelas bawah. kedua, mengelompokkan data yang sesuai dengan fokus penelitian.

Teknik analisis data dalam penelitian ini adalah deskriptif. Setelah menyelesaikan tahap pengumpulan data, peneliti kemudian menganalisis data. Langkah-langkah analisis data dalam penelitian ini, yakni (1) mempersiapkan dan mengolah data, (2) membaca data yang terdapat dalam kedua novel (3) menganalisis lebih dalam dan men-coding data, (4) menerapkan proses coding untuk mendekripsikan bagian yang sama dan bagian yang beda dalam novel, (5) menginterpretasikan atau memaknai data dalam novel Suti karya Sapardi Djoko Damono dan Gumam Tebing Menoreh karya Siwi Nurdiani,(6) penarikan simpulan temuan.

\section{HASIL DAN PEMBAHASAN}

\section{HASIL}

Berdasarkan hasil kajian terhadap teks novel Suti karya Sapardi Djoko Damono dan teks novel Gumam Tebing Menoreh karya Siwi Nurdiani, diperoleh temuan yang menggambarkan adanya mekanisme kekerasan simbolik, habitus kelas atas, dan kelas bawah. Mekanisme eufemisme berupa pemberian, belas kasih, perintah, penolakan secara halus. Mekanisme sensorisasi berupa arahan.

Secara umum kedua novel tersebut mendeskripsikan hubungan antara masyarakat kelas atas dan kelas bawah. Hubungan tersebut terdapat kekerasan simbolik melalui mekanismemekanisme atau cara-cara yang halus agar yang didominasi tidak merasakan adanya tindak kekerasan. Selain itu, temuan penelitian ini memfokuskan pada mekanisme kekekerasan simbolik yang dilakukan oleh kelompok sosial atas terhadap kelompok sosial bawah.

Mekanisme kekerasan simbolik menjelaskan cara kerja dari kekerasan simbolik yang dilakukan oleh pendominasi terhadap yang didominasi. Mekanisme kekerasan yang dilakukan kelas atas secara signifikan sehingga kelas yang didominasi tidak sadar bahwa dirinya menjadi objek kekerasan. Banyak mekanisme atau cara yang digunakan kelompok atas untuk memaksakan habitusnya. Kekerasan simbolik dapat beroperasi melalui bahasa maupun tingkah laku.

\section{Eufemisme Berupa Perintah}

Novel Suti karya Sapardi Djoko Damono dan novel Gumam Tebing Menoreh karya Siwi Nurdiani terdapat bentuk mekanisme kekerasan simbolik berupa perintah yang dilakukan oleh pihak pendominasi terhadap yang didominasi. Pihak yang didominasi tidak sadar bahwa ia meupakan korban dari tindak kekerasan. Mereka yang didominasi tidak memprotes bahkan menganggap hal tersebut wajar terjadi. Perintah merupakan bentuk mekanisme kekerasan simbolik, seperti perintah majikan terhadap pembantu untuk menemani dan merawat orang sakit atau peintah guru kepada siswa untuk mengerjakan tugas mengutarakan sebuah pendapat.

Data (1)

"Kamu harus ikut, Sut. Siapa nanti disana yang mengurus Bapak? Kan sakitnya belum sembuh benar." (Damono, 2015: 101).

Data (1) menunjukkan mekanisme kekerasan simbolik melalui eufemisme berupa perintah. Meskipun dianggap sebagai anak oleh keluarga Sastro, tetapi Suti tetaplah pembantu yang harus mematuhi perintah majikannya. Selain harus membereskan pekerjaan rumah, Suti juga diperintahkan untuk menemani majikannya yang sakit selama bepergian. Perintah merupakan bagian dari bentuk mekanisme kekerasan simbolik.

\footnotetext{
Data (2)

"Harap perhatikan. Tampaknya Indonesia harus menerima kenyataan pahit, karena pertandingan piala AFF. Putaran pertama di Stadion Bukit Jalil Malaysia, Indonesia kebobolan gawang, tiga-kosong. Malaysia begitu gencar memberikan tekanan pada Indonesia. pemain Indonesia tampaknya tak berdaya bertanding dengan Malaysia. Dari kutipan informasi tersebut, silakan berikan tanggapan yang logis". Inilah kesempatan Ning merebut simpati siswa baru di kelas Bahasa Indonesia (Nurdiani, 2018: 26-27).
}

Data (10) merupakan mekanisme kekerasan simbolik. Ning memberi tugas kepada muridnya menulis sebuah pendapat. Ning sengaja memilih tema tentang pertandingan bola antara Indonesia dan Malaysia agar para siswa antusias dalam mengerjakan tugas yang diberikan oleh Ning tersebut. Tema yang dipilih oleh Ning ternyata menarik minat para siswa dan mereka mengerjakan tugasnya dengan suka cita, memberikan tanggapan tanpa merasa dipaksa atau terpaksa. 


\section{Eufemisme Berupa Pemberian}

Pemberian (hadiah) sesuatu yang dilakukan oleh pihak pendominasi terhadap yang didominasi juga merupakan salah satu bentuk pemberian akan mengakibatkan yang didominasi semakin betah atau senang melakukan hal-hal yang menjadi tujuan pendominasi. Cara kerja kekerasan simbolik berupa pemberian hadiah yang dilakukan oleh pendominasi terhadap yang didominasi. Pemberian hadiah akan menyebabkan yang didominasi suka rela melakukan apa yang telah di perintahkan oleh yang mendominasi

Data (3)

Suti selalu mendapat bagian abon kalau makan, tetapi lauk yang didoyaninya terutama dendeng. Sesekali kalau masuk Toko Obral, sebuah toko serba ada, Bu Sastro membelikannya kutang atau bahkan celana dalam. Dan kadang-kadang juga rok. (Damono, 2015: 59).

Pemberian hadiah yang dilakukan oleh pendominasi terhadap yang didominasi merupakan salah satu bentuk mekanisme kekerasan simbolik. Pemberian hadiah tersebut tentunya terdapat tujuan terselubung agar tetap mempertahankan kekuasaan dan juga mempermudah pekerjaan. Bu Sastro merupakan seorang istri priyayi yang disegani masyarakat. Ia mempunyai seorang pembantu bernama Suti. Bu Sastro menyukai kinerja Suti yang ulet dan tidak rewel sehingga pekerjaan rumahnya menjadi ringan dan cepat selesai. Sebagai seorang istri dari seorang priyayi, $\mathrm{Bu}$ Sastro merupakan orang yang mempunyai kekuasaan. Bu Sastro memberikan hadiah kepada pembantunya bukan tidak mempunyai tujuan akan tetapi hal tersebut menjadikan yang didominasi menjadi semakin betah kerja di rumahnya dan yang didominasipun juga menerima tanpa mengalami rasa curiga yang didominasi menganggap hal tersebut adalah suatu hal wajar dan memang seharusnya diterima dengan senang hati.

Data (4)

"Itu akan kalian mengerti nanti! Ibu tidak akan menuntut yang muluk-muluk. Yang terpenting hari ini, hari ini kalian mencoba menulis cerita, apapun yang ingin kalian tulis!

"Kita bebas menulis apa saja, kan, Bu? Tanya seorang siswa.

"Tulis dulu apa yang ingin kalian tulis".

Ning telah merencanakan untuk memberi penghargaan terhadap sekecil apapun usaha mereka untuk menulis. Menghilangkan kete- gangan dan rasa takut dalam pembelajaran itu. (Nurdiani, 2018:140-141).

Data (4) merupakan mekanisme kekerasan simbolik berupa pemberian hadiah yang dilakukan Ning terhadap siswa. Kebebasan yang diberikan Ning terhadap siswa akan tentang tema menulis cerpen juga tidak dibatasi menjadikan siswa lebih leluasa berpikir dalam menciptakan cerpen sesuai dengan keinginan dan pengalaman masing-masing. Tidak hanya memberikan tugas, tetapi Ning juga menghargai hasil kerja siswa atau yang dikenal dengan reward. Reward atau pemberian penghargaan akan menjadikan siswa lebih bersemangat dalam mengerjakan tugas dan lebih antusias dalam mengikuti pelajaran. Pemberian reward juga akan mengakibatkan siswa tidak tegang dan takut mengikuti pelajaran, justru mereka akan lebih tertarik. Eksistensi Ning sebagai guru, akan lebih disukai siswa.

\section{Eufemisme Berupa Belas Kasih}

Bentuk mekanisme kekerasan simbolik juga berupa belas kasih. Belas kasih bertujuan untuk memberikan pertolongan kepada yang didominasi. namun, dibalik kebaikan yang dilakukan oleh pendominasi tersebut, terdapat maksud atau tujuan terselubung. Eufemisme berupa belas kasih dalam novel Suti dan novel Gumam Tebing Menoreh sikap belas kasih dilakukan oleh $\mathrm{Bu}$ Sastro terhadap Suti, dan Molen terhadap Ning. Belas kasih dalam kedua novel tersebut terdapat pada data berikut.

Data (5)

"Suti, kamu anak cantik, gak suka ikut ributribut. Kami sayang padamu, kamu tahu, kan?"

"Kalau kamu ada apa-apa, kalau ada yang ngapa-ngapain kamu, bilang sama Ibu, ya? Kata Bu Sastro tiba-tiba.

"Inggih, Bu." (Damono, 2015:49-50).

Data (5) menunjukkan adanya mekanisme kekerasan simbolik berupa belas kasih dan perhatian. Belas kasih dan perhatian yang diberikan Bu Sastro terhadap Suti hampir sama yang diberikan oleh orang tua terhadap anaknya. Bu Sastro juga seringkali mengingatkan Suti agar lebih berhati-hati terhadap pemuda-pemuda yang terkadang sering mengganggunya. Tetapi meskipun demikian, Suti hanyalah seorang pembantu yang harus mematuhi perintah majikannya. Mekanisme kekerasan simbolik melalui belas kasih lainnya ditunjukkan pada data (6). 


\begin{abstract}
Data (6)
"Jangan pikirkan soal biaya. Kamu akan tinggal di asrama sebagai fasilitas seorang ustadzah. Kurasa itu juga bisa membantumu lebih ringan, tak perlu memikirkan biaya kos. Semua juga sudah tahu, bagaimana kondisi finansial seorang GTT itu." (Nurdiani, 2018:136).
\end{abstract}

Data (6) merupakan mekanisme kekerasan simbolik berupa belas kasih yang dilakukan Molen terhadap Ning. Penghasilan Ning sebagai guru GTT tidak cukup untuk memenuhi kebutuhan sehari-hari apabila uangnya juga digunakan untuk membayar uang kontrakan. Belas kasih yang dilakukan Molen agar Ning dapat mengurangi pengeluaran. Selain ditawari tempat tinggal gratis, Ning juga menjadi guru. Hal itu bertujuan agar Ning lebih memperdalam ilmu agamanya di pesantren. Agar terbiasa dengan kegiatan yang juga biasa dilakukan Molen.

\section{Eufemisme Berupa Penolakan secara Halus}

Mekanisme kekerasan simbolik eufemisme berupa penolakan secara halus terdapat dalam novel Suti dan novel Gumam Tebing Menoreh. Penolakan secara halus tersebut berupa penolakan menjodohkan anaknya dengan orang atau gadis yang tidak sekelas atau tidak sepadan. Penolakan tersebut tidak dilakukan secara terang-terangan melainkan dengan cara yang halus yaitu bahasa atau kalimat yang menyakitkan, namun menggunakan bahasa yang sopan.

\footnotetext{
Data (7)

"Lho, masa dibiarkan saja Kunto keluyuran ke mana-mana sama pembantu yang punya suami," Kan tentu ada mindho yang akan siap menerima Kunto sebagai istrinya" (Damono, 2015: 116).
}

Banyak orang yang tidak menyetujui hubungan Suti dan Kunto. Ekstensi dan peran Suti hanyalah sebagai seorang pembantu. Tidak pantas apabila keduanya berpacaran apalagi merencanakan untuk segera menikah. Karena selain berasal dari dua kelas yang berbeda, Suti juga masih berstatus sebagai istri orang lain. Sebagai orang yang berasal dari keluarga kaya dan priyayi, Kunto hanya pantas menikah dengan orang atau gadis yang memiliki kesamaan dengan Kunto yaitu dari keluarga priyayi.

Data (8)

"Dia itu guru di aliyah, Ummi, Guru Bahasa Indonesia". "Ummi, saya sudah mantap untuk membina rumah tangga dengan dia" "Ummi... Molen minta restu dari Ummi". "Ummi sudah memberi pertimbangan untukmu. Jangan sampai langkah yang kamu ambil justru menjadi penghancur kehidupanmu. Sebab rumahtangga itu ibaratnya bangunan. Dari bahan-bahannya, perencanaannya, fondasi, tiang serta dinding serta aksesorisnya yang membuat bangunan itu indah dan nyaman" ( Nurdiani, 2018: 81-177).

Penolakan secara halus juga termasuk salah satu mekanisme kekerasan simbolik. Ummi adalah sosok Ibu sekaligus istri dari seorang kiayi. Ummi tidak menyetujui apabila Molen (anaknya) menikah dengan seorang wanita yang berprofesi sebagai guru honor di salah satu lembaga pendidikan swasta. Ummi menginginkan agar anaknya mencari calon istri yang yang berasal dari keluarga kiai juga. Nasihat yang diberikan Ummi merupakan bentuk penolakan secara halus agar ia dapat mengulur waktu dan meyakinkan anaknya bahwa wanita yang dipilih merupakan wanita yang tidak pantas untuk menjadi bagian dari keluarganya. Wibawa Ummi akan menurun dan tidak terpandang lagi di masyarakat.

Data (9)
"Meski Ummi mengatakan mungkinkah bila
kangkung punya atau kualitas seperti halnya
kualitas pada jati? Kangkung hanyalah tanam-
an merambat yang hidup di tempat yang
banyak air meski itu comberan". (Nurdiani,
2018:175).

Tanaman kangkung tidak akan bisa menyamai tanaman Jati. Itulah perumpaan yang menggambarkan perbedaan antara Ning dan Molen. Perbedaan kelas antara Ning dan Molen membuat Ibu Molen berpikir kesekian kali untuk menerima Ning sebagai menantunya. Ning diibaratkan tanaman kangkung yang merambat dan tumbuh di air bahkan air kotor karena Ning bukan berasal dari keluarga kiai dan hanya berprofesi sebagai guru honor, sedangkan Molen diibaratkan tanaman jati yang berbatang kuat karena Molen adalah putra tunggal dari keluarga kiai yang akan menjadi pewaris pesantren milik ayahnya. Tanaman kangkung tidak akan bisa menyamai tanaman Jati.

\section{Mekanisme Sensorisasi}

Mekanisme sensorisasi menjadikan kekerasan simbolik terlihat sebagai bentuk sebuah pelestarian semua bentuk nilai yang dianggap 
sebagai moral kehormatan, seperti kesantunan, kesucian, kedermawanan yang biasanya dipertentangkan dengan moral yang rendah, seperti kekerasan, kriminal, ketidakpastian, amoral, dan ketamakan.

Mekanisme sensorisasi bisa dilakukan dengan dan cara mengatur dan mengarahkan akses ungkapan yang dilakukan oleh seseorang yang dianggap memiliki simbol moral, dalam hal ini adalah priyayi, bangsawan, dan agamawan. Mekanisme sensorisasi yang terdapat dalam novel Suti dan novel Gumam Tebing Menoreh berupa moral kehormatan yang dijunjung oleh seseorang yang memiliki kedudukan dalam masyarakat. Mekanisme sensorisasi dalam kedua novel tersebut berupa pelestarian moral kehormatan dan kesantunan.

Data (10)

$\mathrm{Bu}$ Sastro menanggapi tuduhan terhadap anak bontotnya. Dengan lantang tetapi rapi susunan kata-katanya, priyayi kota itu membela Dewo. "Anjing Ibu pernah nggigit orang, kan?" Tuduhannya tegas. Dan memang benar. Janda itu diam tidak tahu harus menjawab apa.

"Apa Ibu? Malah peduli? Apa Ibu minta maaf pada yang digigit? Malah menyalahkannya, kan? Malah menuduhnya telah mengganggu anjing Ibu, kan?”( Damono, 2015:48).

$\mathrm{Bu}$ Sastro merupakan seorang priyayi yang ingin mempertahankan kehormatan diri dan anaknya yang dituduh melakukan tindakan pencurian. Data (10) menunjukkan adanya mekanisme kekerasan simbolik berupa sensorisasi. Sebagai seorang priyayi, Bu Sastro menyampaikan kekecewaanya dengan menggunakan bahasa yang sopan. Kemarahan Bu Sastro dikarenakan ulah tetangganya yang selalu berbuat keributan dan menuduh Dewo (anak Bu Sastro) sebagai pencuri anjing. Namun demikian, Bu Sastro menyampaikan kekecewaanya dengan menggunakan kata-kata yang sopan. Hal itu berdampak pada keseganan masyarakat kepada Bu Sastro. Bu Sastro tetap terlihat berwibawa di hadapan masyarakat. Meskipun keduanya sama sama berasal dari kelompok kelas atas. Cara penyampaian kritikan yang tegas, membuat $\mathrm{Bu}$ Mayor tidak dapat melawan perkataan Bu Sastro.

Data (11)

"Sungguh tempat ini akan terkena laknat, kalian telah mencoreng kesuciannya. Kalian, yang dianggap senior kenapa malah memberi teladan bejat seperti ini !!!" Kiai benar-benar murka." Maulana! Kalau seperti ini, sama halnya kamu meludahi wajah uwakmu sendiri, wajah orang tuamu sendiri."

"Darimana semua gambar ini?"

"Tidak penting. Yang penting adalah hisab untuk kalian. Kalian telah melanggar larangan yang ada di pesantren ini, menodai kesuciannya!"

Jalan yang terbaik adalah kalian harus menikah Sebab, bila tidak kalian hanya akan menumpuk dan menambah dosa."(Nurdiani, 2018: 183184).

Kiai Hasyim adalah seorang agamawan sekaligus pemimpin pesantren. Sebagai seorang kiai, Kiai Hasyim selalu melestarikan nilai-nilai positif dalam lingkungannya. Hal tersebut tampak ketika Molen dan Ning melanggar aturan yang ada dalam pesantren tersebut. Kedudukan Kiai Hasyim sebagai pemimpin, menjadikan kiai Hasyim disegani, dan dipatuhi semua kata-kata dan tingkah lakunya. Kemarahan Kiai Hasyim ketika mengetahui keponakannya, Molen, telah melakukan tindakan yang tidak sesuai dengan norma agama. Molen dan Ning dianggap telah menodai kesucian pesantren. Tindakan Molen dan Ning juga akan mengakibatkan santri yang lain dapat berbuat hal yang sama seperti yang dilakukan oleh Molen dan Ning. Sebagai pimpinan pesantren, Kiai Hasyim memberikan hukuman kepada Molen dan Ning. Kiai Hasyim mempunyai wewenang untuk memberikan hukuman kepada orang yang telah melanggar aturan pesantren.

\section{Habitus}

Habitus merupakan hasil proses internalisasi di masa lalu yang terbawa ke masa depan. Habitus juga dapat didefinisikan sebagai gaya hidup, nilai-nilai, dan harapan yang dimiliki oleh kelompok sosial tertentu. Habitus dalam novel Suti dan novel Gumam Tebing Menoreh terdapat dua macam habitus yaitu habitus kelas atas dan habitus kelas bawah.

\section{Habitus Kelas Atas}

Habitus kelas atas dalam novel Suti dan novel Gumam Tebing Menoreh juga terdapat habitus kelas atas. Habitus tersebut berupa harapan dan gaya hidup.

\section{Harapan}

Tokoh yang mempunyai harapan dalam novel Suti adalah Bu Sastro, dengan pertolongan Mbah Parmin ia dapat terbebas dari kondisi 
kesepian, sedangkan harapan yang terdapat dalam novel Gumam Tebing Menoreh adalah harapan untuk mendapatkan menantu yang sepadan dengan anaknya.

Data (12)

"Mbah Parmin bilang Dewo akan membebaskanku dari rasa sunyi yang tumbuh jauh di bawah kesadaranku. Pikiran itu ditampungnya dari pertemuannya berulang-ulang dengan orang pandai yang menjadi sesepuh makam. Mula-mula ia merasa menjadi bayang-bayang Mbah Parmin, tetapi lama-lama ia merasa Mbah Parmin yang berubah wujud menjadi bayang-bayangnya. Pikiran itua membuatnya lega dan merasa selalu aman. (Damono, 2015:157-158).

Penghormatan $\mathrm{Bu}$ Sastro pada Mbah Parmin diwujudkan dengan melakukan ritual yang rutin di lakukan setiap malam Jum'at. Bu Sastro berharap agar diberikan ketenangan dan terbebas dari rasa kesepian setelah ditinggal anak sulungnya merantau dan ditinggal oleh suaminya yang telah meninggal. Anak bungsunya merupakan orang yang menjadi harapan $\mathrm{Bu}$ Sastro untuk menghilangkan rasa kesepiannya. Sebelumnya, Bu Sastro tidak pernah menyadari bahwa Dewo adalah penolong bagi dirinya. Harapan tersebut muncul ketika Bu Sastro ketika berkonsultasi dengan juru kunci makam Mbah Parmin.

Data (13)

"Jika seperti itu tak bagus juga. Besar kemungkinan pesantren malah kehilangan jati dirinya, kehilangan arah. Ina yang modernis, justru membela pesantren apa adanya. Aku Cuma mau mengingatkan soal Ning, yang memang bukan nasab pesantren mana pun. Kamu tahu itu kan? Kamu siap dengan segala resiko?" (Nurdiani, 2018:198).

Ina juga tidak menyetujui rencana pernikahan Molen dengan Ning. Molen yang merupakan putra dari keluarga kiai juga harus mendapat istri yang juga berasal dari keluarga kiai. Hal itu bertujuan agar pesantren tetap mempertahankan budaya dan identitasnya. Ning tidak pantas menjadi istri Molen karena Ning berasal dari kelurga biasa.

\section{Gaya Hidup}

Gaya hidup seseorang atau kelompok tertentu dapat dilihat dari cara berpakaian, kebiasaan, dan lainnya. Gaya hidup kelompok kelas atas dengan gaya hidup kelompok kelas bawah terdapat perbedaan. Gaya hidup kelompok kelas atas pada novel Suti dan novel Gumam Tebing Menoreh berupa menu makanan wajib yang harus ada ketika mereka makan. Menu masakan yang disantap oleh keluarga kiai berupa gulai kambing, sedangkan menu masakan yng sering disantap oleh keluarga Raden Sastro adalah abon daging.

\section{Data (14) \\ Ning tak bisa menolak ketika harus ikut makan bersama mereka. Ning hanya mematung, ke- tika Ummi menyendokkan nasi dan menuang- kan kuah gulai kambing ke piringnya. \\ "Sudah berapa lama di Demak?" Lembut Ummi bertanya. \\ "Baru enam bulan ini, Ummi." (Nurdiani, 2018: 80).}

Menu makanan yang disajikan juga bisa menunjukkan gaya hidup seseorang, seperti yang menjadi menu yang disantap oleh keluarga Molen. Karena keluarga Molen adalah keluarga kaya, ia menyajikan makanan yang harganya mahal dan bahan bakunya terdiri atas daging kambing. Hal itu digambarkan ketika mereka mengadakan pertemuan keluarga antara Ning dan keluarga Molen menu makanan yang disajikan berupa gulai kambing. Ciri habitus yang menunujukkan bahwa data (14) merupakan habitus kelas atas adalah cara berbicara. Cara berbicara Ummi yang pelan dan lembut karena ia merupakan istri seorang kiai dan harus menunjukkan kepribadian yang baik kepada orang lain.

Data (15)
Sebulan sekali bu Sastro mengajaknya ke per-
tokoan di Coyudan untuk beli ini itu, mampir
ke Toko Abon tampaknya suatu keharusan.
Yang mengantarkan selalu Sarno, kalau dia
tidak lagi nukang. (Damono, 2015:59).

Data (15) menunjukkan kekerasan simbolik dalam bentuk gaya hidup. Gaya hidup seseorang yang berasal dari kelas atas tentunya berbeda dengan gaya hidup seseorang yang berasal dari kelas bawah. Salah satunya dari menu makanan yang disantap setiap harinya. Bu Sastro sebulan sekali berbelanja kebutuhan rumah tangga dan itu merupakan kegiatan yang rutin dilakukan. Produk makanan yang wajib dibeli salah satunya adalah Abon karena makanan tersebut termasuk salah satu makanan favorit keluarganya. Hal tersebut sudah menjadi kebiasaan dalam keluarga Sastro di mana abon merupakan produk makanan yang wajib dibeli sebagai lauk. 


\section{Habitus Kelas Bawah}

Habitus kelas bawah dalam novel Suti dan Gumam Tebing Menoreh berupa harapan dan gaya hidup. Temuan terkait habitus ini dipaparkan sebagai berikut.

\section{Harapan}

Habitus kelas bawah dalam novel Suti dan novel Gumam Tebing Menoreh berupa harapan yang dimiliki oleh kelompok sosial bawah. Mereka berharap agar menjalani kehidupan yang lebih baik di masa depan. Gaya hidup yang dilakukan oleh kelompok sosial bawah berupa menu masakan yang dimakan kesehariannya yang berasal dari hasil ladang.

Data (16)

“O, itu. Ya, moga-moga saja. kita dapet satu sumur lagi ya. Aku ndak keberatan bantu-bantu ngangsu untuk kamar mandi mereka. Jangan sampai priyayi itu suka bertingkah yang sering meyusahkan macam Bu Mayor yang galaknya seperti anjing piaraannya.” (Damono, 2015).

Harapan merupakan bagian dari habitus. Harapan pada data (16) adalah harapan yang dimiliki oleh kelompok sosial bawah atau yang terdominasi. Suti adalah bagian dari individu yang terdominasi. Hadirnya keluarga priyayi atau keluarga kaya di desanya membuat Suti mempunyai harapan agar keluarga kaya tersebut memberi tumpangan gratis mencuci di sumurnya sehingga ia tidak mencuci pakaiannnya di sungai yang setiap hari ia lakukan sebagai kegiatan rutin. Suti juga berharap agar keluarga Sastro tersebut mempunyai sifat yang baik dan ikhlas memberikan tumpangan sumur pada dirinya.

Data (17)

"Mbok ya biarkan dulu. Dia itu sudah dewasa biar saja dia memilih keputusannya sendiri. Sebagai orang tua, kita cuma wajib memberi do'a restu. Siapa tahu Ning malah jadi pegawai di sana. Ya to, Nduk? Kan kita semua ikut senang".Seperti itulah Bapak. Amat berambisi, ingin sekali anaknya menjadi pegawai yang memiliki status, tentunya juga punya jaminan untuk hari tua. Tidak seperti Bapak yang bekerja sebagai buruh tani. Itupun kini sudah jarang ada yang menawari karena usianya yang semakin renta. (Nurdiani, 2018)

Nasib yang kurang beruntung membuat seseorang mempunyai keinginan untuk menjadi lebih baik dari segi ekonomi atau keuangan.
Begitu juga yang dialami oleh keluarga Ning yang berasal dari desa. Untuk memenuhi kebutuhan sehari-hari, keluarga Ning hanya mengandalkan hasil kebun yang tidak seberapa. Untuk itulah Bapaknya tidak ingin Ning menikah muda dan sangat menginginkan agar anaknya tersebut menjadi penolong untuk memperbaiki kondisi perekonomian keluarga dengan menjadi Pegawai Negeri Sipil.

\section{Gaya Hidup}

Habitus merupakan hasil proses internalisasi di masa lalu yang terbawa ke masa depan. Habitus juga dapat didefinisikan sebagai gaya hidup, nilai-nilai, dan harapan yang dimiliki oleh kelompok sosial bawah.

Data (18)

Suti dan Tomblok, yang nama lengkapnya $\mathrm{Pa}-$ riyem, biasa ngobrol di pinggir sungai setiap pagi ketika mereka sedang mencuci pakaian. Sungai adalah salah satu bagian penting kehidupan di kampung itu, bukan hanya sebagai tempat cuci tetapi juga sebagai pusat penyebarluasan cerita burung. (Damono, 2015).

Suti berasal dari keluarga miskin. Hal itu ditunjukkan dengan kebiasaanya mencuci pakaian di sungai setiap harinya. Bagi masyarakat di kampung, sungai adalah tempat yang penting, selain dijadikan tempat untuk mencari pasir dan tempat mencuci pakaian, Sungai juga dijadikan tempat untuk membahas cerita-cerita yang terjadi di lingkungan sekitar. Data (18) merupakan salah satu bentuk habitus berupa gaya hidup. Kebiasaan tersebut tidak hanya dilakukan oleh Suti, tetapi juga Tomblok yang merupakan Sahabat Suti.

\section{Pembahasan}

Sesuai dengan hasil temuan penelitian, pembahasan hasil penelitian dibagi menjadi tiga bagian, yaitu mekanisme eufemisme, mekanisme sensorisasi, habitus kelas atas dan bawah. Mekanisme kekerasan simbolik merupakan cara kerja dari kekerasan simbolik. Cara yang dilakukan yang dilakukan oleh kelompok sosial atas untuk mensosialisasikan habitusnya kepada kelompok kelas bawah. Mekanisme yang halus, samar, dan berbeda dengan mekanisme kekerasan pada umumnya. Melalui bahasa, kekerasan simbolik dalam sebuah relasi sosial menyembunyikan kekuatan memaksanya secara sah melalui statemen-statemen yang dituturkan oleh pihak yang mendominasi. Melalui bahasa, pihak 
dominan menanamkan habitus tertentu, seperti ketaatan pada norma, ketertundukan pada ideologi, gaya hidup, dan lainnya (Ulya, 2016).

\section{Mekanisme Eufemisme}

Mekanisme kekerasan simbolik yang pertama adalah mekanisme eufemisme. Secara umum eufemisme didefinisikan sebagai penghalusan bahasa atau menghaluskan bahasa yang awalnya kasar menjadi diperhalus dengan tujuan agar lawan bicara tidak tersinggung dengan apa yang dikatakan atau diungkapkan. Namun demikian, dalam versi mekanisme eufemisme Pierre Bourdie mekanisme eufemisme tidak hanya berfokus pada penghalusan bahasa saja, melainkan juga melalui pemberian, belas kasih, perintah. Eufemisme menjadikan kekerasan simbolik menjadi tidak terlihat seperti bentuk kekerasan pada umumnya. Melalui eufemisme, kekerasan simbolik bekerja sangat halus sehingga tidak dapat dirasakan sebagai sebuah kekerasan dan berlangsung di bawah alam sadar. Bentuk eufemisme yang terdapat pada kedua novel yaitu berupa penghalusan bahasa, perintah, pemberian, dan belas kasih.

Mekanisme eufemisme dalam novel Suti karya Sapardi Djoko Damono dan novel Gumam Tebing Menoreh karya Siwi Nurdiani digunakan untuk meremehkan kemampuan orang lain. Hal tersebut dilakukan oleh seorang priyayi yang tidak terlalu puas dan memandang rendah orang lain yang pendidikannya lebih rendah daripada priyayi tersebut. Penghalusan bahasa digunakan untuk melakukan penolakan menjodohkan anak dengan wanita yang dianggap tidak mempunyai bebet, bibit, bobot yang tidak jelas dan bukan berasal dari keluarga priyayi maupun kiai. Hal itu bertujuan agar posisi, asal-usul, serta budaya keluarga pendominasi tetap dipertahankan.

Perintah dilakukan oleh majikan kepada pembantu sebagai bentuk sebuah kekuasaan atau penerapan dari sebuah kekuasaan. Perintah dalam novel Suti dilakukan oleh majikan yang merupakan seorang priyayi kepada pembantu. Dengan memberikan perintah, pendominasi melakukan aksi kekerasan simboliknya karena memperlakukan yang didominasi sesuai dengan keinginannya, melakukan segala sesuatu yang dibutuhkan oleh pendominasi. Mekanisme eufemisme berupa perintah dalam kedua novel berupa menjadi pembantu pengganti yang bertujuan untuk meringankan beban kerja rumah tangga majikan, berpenampilan sesuai dengan aturan lembaga, berpenampilan sesuai keinginan atau kriteria keluarga kiai. Mereka yang mendapat perintah melakukannya dengan senang hati melaksanakan perintah majikan dan atasannya karena mereka menganggap hal tersebut adalah kewajiban dan harus dilakukan dengan sepenuh hati.

Pemberian dalam kedua novel berupa membelikan barang mahal yang dilakukan oleh majikan kepada pembantu, Melalui pemberian inilah, pihak pendominasi juga berusaha memaksakan dan mensosialisasikan habitusnya kepada kelompok kelas bawah, seperti tokoh priyayi pada novel Suti yang sering membelikan barang-barang mahal yang sebelumnya belum pernah dibeli atau dipakai oleh secara langsung kelompok kelas atas (priyayi tersebut) bahwa habitus kelas atas memanglah demikian. Memakai barang dengan harga yang sulit dijangkau oleh masyarakat kelas bawah. Pemberian yang kedua berupa mengenalkan sebuah pengetahuan dan pengalaman yang sebelumnya tidak pernah dirasakan dan dilalui oleh yang terdominasi. Hal tersebut dilakukan oleh majikan terhadap pembantu. Pembantu yang mempunyai sifat rasa ingin tahu yang besar membuat posisi pembantu menadapatkan banyak pengetahuan. Mengenalkan sebuah pengetahuan menonton bioskop, membaca dan meminjam buku di perpustakaan. Hal ini pendominasi mempunyai tujuan mengenalkan, memaksakan, dan mensosialisasikan habitusnya kepada kelompok kelas bawah.

Belas kasih dalam kedua novel berupa memberikan pertolongan pada kelompok terdominasi. Belas kasih yang terdapat dalam novel Suti berupa sebuah pengakuan bahwa pembantu dipekerjakan oleh keluarga priyayi juga dianggap sebagai seorang anak. Namun demikian, di balik belas kasih yang dilakukan oleh keluarga priyayi tersebut terdapat maksud terselubung. Pembantu yang merupakan gundik dari salah satu anggota keluarga priyayi. Pak Sastro melakukan perselingkuhan dengan pembantunya, yaitu Suti. Pengakuan tersebut dilakukan agar orang lain tidak curiga bahwa keduanya melakukan hubungan terlarang. Belas kasih yang terdapat dalam novel Gumam Tebing Menoreh. Perlakuan pemerintah yang berbeda terhadap guru honor dan guru yang telah berstatus PNS membuat guru honor terancam keadaannya sebagai guru. Beberapa atasan memberikan solusi agar guru honor tetap mendapat jatah jam mengajar dan tidak dibebas tugaskan. Belas kasih yang dilakukan oleh pendominasi bertujuan agar terhindar dari pendapat atau opini negatif masyarakat tentang perlakuan yang dilakukan oleh 
pejabat-pejabat di sekolah terhadap guru honor yang dilakukan secara semena-mena. Dengan demikian, nama baik dan wibawa mereka akan tetap terjaga.

\section{Mekanisme Sensorisasi}

Mekanisme kekerasan simbolik berupa Mekanisme sensorisasi menjadikan kekerasan simbolik tampak seperti pelestarian moral positif. Menurut Widarmanto (2014:19) sensorisasi dilakukan dengan cara mengatur dan mengarahkan akses ungkapan yang dilakukan oleh seseorang yang dianggap memiliki simbol moral, dalam hal ini adalah priyayi, bangsawan, dan agamawan. Bentuk-bentuk mekanisme kekerasan simbolik berupa kesucian yang biasanya mendapat tentangan

Mekanisme sensorisasi yang terdapat dalam kedua novel berupa pelestarian moral positif berupa pentingnya menerapkan nilai kesucian, kesopanan, dan sikap bertanggung jawab dalam kehidupan sehari-hari. Mekanisme sensorisasi dalam kedua novel dilakukan oleh priyayi, kiai, dan guru.

Pelestarian moral positif berupa kesopanan dilakukan oleh seorang priayi (Bu Sastro) terhadap Bu Mayor. Bu Sastro merasa jengkel ketika anaknya dituduh melakukan tindakan kriminal, dituduh sebagai seorang pencuri. Namun kejengkelannya dan pembalasan yang dilakukan kepada lawannya disampaikan dengan bahasa yang sopan khas seorang priyayi, Bu Sastro tetap menata kata-katanya untuk menjaga wibawanya sebagai seorang priyayi.

Mekanisme sensorisasi yang kedua adalah pelestarian moral positf berupa kesucian. Mekanisme ini dilakukan oleh seorang kiai terhadap Molen yang dianggap mencemarkan kesucian pesantren dengan melakukan tindakan-tindakan tidak senonoh kepada Ning. Molen dan Ning merupakan dua orang penentang aturan pesantren, kiai Hasyim yang mempunyai kekuasaan tertinggi menjatuhkan hukuman kepada keduanya agar tidak tindakan yang dianggap tercela tersebut tidak ditiru oleh santri yang lain. Dengan tindakan yang demikian, wibawa kiai Hasyim sebagai seorang pemimpin pesantren tetap terjaga di hadapan santri dan di tengah-tengah masyarakat.

Mekanisme sensorisasi yang ketiga yaitu pelestarian moral positif berupa tanggung jawab. Hal itu dilakukan oleh guru terhadap muridmuridnya yang merupakan salah satu kelompok pementasan teater. Salah satu kelompok yang ingin mengundurkan diri dari tugas mementaskan teater pada akhir semester. Kurangnya tanggung jawab yang dilakukan oleh muridnya tersebut, sang guru menghadapi dengan tenang dan juga menjelaskan pentingnya tanggung jawab terhadap tugas yang harus diselesaikan.

\section{Habitus}

Habitus adalah pola pikir atau hasil internalisasi yang dialami oleh kelompok sosial tertentu. Meskipun habitus sifatnya permanen tetapi habitus juga akan mengalami perkembangan dan perubahan. Habitus dapat berupa nilai-nilai, gaya hidup, maupun harapan yang dimiliki oleh kelompok sosial tertentu (Martono, 2012).

Gaya hidup juga merupakan bagian dari habitus. Gaya hidup yang terdapat pada keluarga $\mathrm{Bu}$ Sastro adalah keharusan membeli menu makanan tertentu (abon) sebagai pendamping makanan pokok yaitu nasi. Gaya hidup dalam novel Gumam Tebing Menoreh adalah kebiasaan keluarga kiai menyantap menu makanan khas yang bahannya berasal dari daging kambing yang harganya mahal. Gulai menjadi makanan wajib dan khas yang biasanya disajikan untuk para tamu atau acara tertentu.

Habitus kelas bawah dalam novel Suti dan novel Gumam Tebing Menoreh adalah harapan, gaya hidup, dan nilai-nilai yang diterapkan oleh masyarakat kelas bawah. Ketidaksadaran kultural yang melekat pada habitus senantiasa berulang dari generasi ke generasi (diwariskan secara turun temurun) melalui persepsi maupun tindakan. Skema-skema habitus menyatu kepada nilai-nilai dan gerak-gerik secara otomatis. Habitus juga berkaitan dengan prinsip konstruksi dan evaluasi yang mendasar terhadap dunia sosial yang memberikan strategi bagi individu mengatasi berbagai perubahan tak terduga (Zurmailis dan Faruk, 2017:49).

Harapan yang dimiliki oleh Suti agar keluarga Sastro dapat memberikan tumpangan mencuci di sumur dan memberikan Suti pekerjaan. Dengan demikian, Suti akan mendapatkan penghasilan setiap bulan. Suti yang berasal dari keluarga tidak mampu, tinggal dengan seorang suami dan seorang ibu dengan keadaan ekonomi yang sangat minim membuat Suti juga harus membantu perekonomian keluarganya agar dapat memenuhi kebutuhan sehari-hari.

Harapan yang terdapat dalam novel $G u$ mam Tebing Menoreh adalah harapan orang tua Ning agar anaknya menjadi pegawai negeri sipil, 
dengan demikian perekonomian mereka akan menjadi lebih baik. Hidup yang tidak kekurangan yang telah dialami selama ini.

Gaya hidup kelompok kelas bawah dalam novel Suti adalah kebiasaan Suti dan Tomblok yang selalu mencuci di sungai. Maka dari yang demikian, tumbuhlah harapan agar ada seseorang yang dapat menolong kehidupan dan nasibnya. Gaya hidup yang demikian merupakan hasil pembelajaran lingkungan yang didapatkan ketika di masa lalu dan terbawa ke masa depan.

Gaya hidup kelompok sosial kelas bawah dalam novel Gumam Tebing Menoreh berupa kebiasaan keluarga Ning yang menyantap makanan dari hasil kebun dan kebiasaan ayah Ning yang membuat rokok sederhana. Hasil produksi sendiri yang biasa dilakukan oleh ayah Ning setiap selesai makan. Dengan gaya hidup yang demikian, muncul harapan agar Ning dapat memperbaiki keadaan perekonomian keluarga.

\section{SIMPULAN}

Berdasarkan hasil analisis yang telah dilakukan dalam penelitian ini, disimpulkan bahwa mekanisme kekerasan simbolik merupakan cara yang digunakan untuk memaksakan habitus kelas atas kepada kelas bawah. Mekanisme tersebut berupa mekanisme eufemisme dan mekanisme sensorisasi. Mekanisme eufemisme menjadikan kekerasan simbolik tidak terlihat seperti kekerasan pada umumnya. Bentuk-bentuk yang ditemukan dalam penelitian ini antara lain penghalusan bahasa, perintah, belas kasih, dan pemberian. Melalui mekanisme tersebut, kelompok pendominasi menjalankan aksi kekerasan simboliknya dengan lancar dan tanpa menerima protes dari pihak yang didominasi.

\section{DAFTAR PUSTAKA}

Bourdieu, P. 1990. The Logic of Practice. Cambridge: Polity Press.

Bourdieu, P. 1995. Language and Symbolic Power. Diterjemahkan oleh Gini Raymond \& Matthew Adamson. Cambridge: Polity Press

Bourdieu, P. 1998. La Domination Masculine. Paris: Minuit.

Bourdieu, P. 2010. Dominasi Maskulin. Yogyakarta: Jalasutra.

Damono, S. D. 2015. Suti. Jakarta. Kompas

Link, B. G. \& J. Phelan. 2013. Stigma Power. Social Science \& Medicine, 103: 24-32.
Habitus dalam penelitian ini dibagi menjadi dua macam, yaitu habitus kelas atas dan habitus kelas bawah. Habitus kelas atas berupa gaya hidup yang mewah, harapan untuk tetap melanggengkan kekuasaan, dan nilai-nilai budaya yang terus diterapkan untuk tetap mempertahankan identitas diri di dalam kehidupan masyarakat. Habitus kelas bawah juga berupa harapan, gaya hidup, dan nilai-nilai yang diterapkan dalam kehidupan sehari-hari. Bentuk habitus yang menonjol pada habitus kelas bawah adalah harapan. Harapan untuk menjalani kehidupan dan nasib yang lebih baik di masa depan. Nilai-nilai budaya yang diterapkan oleh masyarakat kelas bawah merupakan nilai-nilai yang dipengaruhi oleh masyarakat kelas atas karena masyarakat kelas bawah mempercayai dengan menerapakn nilai-nilai yang demikian dalam kehidupan sehari-hari akan mendapatkan berkah dan kehidupan yang lebih baik.

Habitus yang paling sering dipaksakan oleh kelompok kelas atas kepada kelompok kelas bawah berupa gaya hidup dan nilai-nilai yang menjadi pedoman hidup dan sering diterapkan oleh kelompok kelas atas. Karena kelas atas beranggapan bahwa habitus kelas atas yang patut di terapkan dam kehidupan sehari-hari.

\section{UCAPAN TERIMA KASIH}

Penulis menyampaikan ucapan terima kasih kepada mitra bestari (reviewers) yang telah memberikan komentar, saran, dan kritikan perbaikan terhadap naskah ini. Bantuan yang diberikan telah membantu penulis meningkatkan kualitas artikel ini.

Martono, N. 2012. Kekerasan Simbolik di Sekolah: Sebuah Ide Sosiologi Pendidikan Pierre Bourdieu. Jakarta: Rajawali Pers.

Nurdiani, Siwi. 2018. Gumam Tebing Menoreh. Yogyakarta: Diva Press

Rusdiarti, S. R. 2003. Bahasa, Pertarungan Simbolik, dan Kekuasaan. Jurnal Basis, Edisi Khusus Pierre Bourdieu, No. 11-12 Tahun ke- 52, edisi November-Desember.

Ulya. 2016. Mewaspadai Kekerasan Simbolik dalam Relasi Orang Tua dan Anak. Palastren, 9 (2): 233-252. 
140 RETORIKA: Jurnal Bahasa, Sastra, dan Pengajarannya, Volume 12, Nomor 2 Agustus 2019, hlm. 128-140

Widarmanto, T. 2014. Kekerasan Simbolik dalam karya-karya Pramoedya Ananta Toer dan Oka Rusmini. Konferensi Nasional Bahasa dan Sastra III. /https://anzdoc.com/kekerasansimbolik-dalam-karya-karya-oka-rusmini-danpramoed.html.
Zurmailis \& Faruk. 2017. Doksa, Kekerasan Simbolik, dan Habitus yang Ditumpangi dalam Kontruksi Kebudayaan di Dewan Kesenian Jakarta. Jurnal Bahasa dan Sastra, 1 (1): 44-72 . 